\title{
Ovarian Cancer pT2c TNM Finding v6
}

National Cancer Institute

\section{Source}

National Cancer Institute. Ovarian Cancer pT2c TNM Finding v6. NCI Thesaurus. Code C60911.

Ovarian cancer involving one or both ovaries with extension or implants on the uterus and/or fallopian tubes, or other pelvic tissues, with malignant cells in either ascites or peritoneal washings. (from AJCC 6th Ed.) 